\title{
MEgALITE: A NEW SPANISH LiteratURE CORPUS FOR NLP TASKS
}

\author{
Luis-Gil Moreno-Jiménez ${ }^{1}$ and Juan-Manuel Torres-Moreno ${ }^{1,2}$ \\ ${ }^{1}$ Laboratoire Informatique d'Avignon, Université d'Avignon, (Avignon) France \\ ${ }^{2}$ GIGL, Polytechnique Montréal, (Québec) Canada
}

\begin{abstract}
In this work we introduce the Spanish Literary corpus MegaLite, a new corpus well adapted to Natural Language Processing (NLP), Computational Creativity (CC), Text generation and others studies. We address the creation of this corpus of literary documents to evaluate or design algorithms in automatic text generation, classification, stylometry and rhetorical analysis, sentiment detection, among other tasks. We have constituted this corpus manually in order to avoir genre classification errors. Near of 5200 works on the genres narrative, poetry and plays constitute this corpus. Some statistics and applications of MegaLite corpus are presented and discussed. The MegaLite corpus will be available to the community as a free resource, under several adequate formats.
\end{abstract}

\section{KEYWORDS}

Emotion Corpus, Spanish Literary Corpus, Learning algorithms, Linguistic resources.

\section{INTRODUCTION}

For many years, the study of the languages has been an area very attractive for the computational community $[10,11]$. With the intention of analysing the linguistic complexity through formal methods, the researchers have proposed an important number of studies in order to detect the main linguistic characteristics for different languages [24], making possible a large number of further researches addressed to Processing of Natural Language (NLP) [2, 15].

Recently, researchers in computing areas have addressed their efforts to simulate the creative human process to create artistic artefacts in an artificial way. The idea is to propose another paradigm to generate this kind of artistic works considering as base the concept of "creative process" introduced by Boden in [1]. As result, a new field in Computational Science has been created, Computational Creativity [19].

Computational Creativity (CC) area has been strongly addressed for many researchers, today we have algorithms able to generate artificially paintings, music, literary works like poems, narratives, poetry, etc. However, we have detected a significant problem in works focused in literature, this is the absence of an enough rich corpus, useful for training or testing process of the proposed models.

The study and constitution of literary corpora is very important for the development and evaluation of models in CC area. However, these studies have been systematically left aside by the researchers, mainly because the complex level of literary discourse, the subjectivity and ambiguity commonly detected in literary texts. Instead, the use of corpora constituted by 
encyclopedic documents (mainly Wikipedia), journals (newspapers or magazines) or specialized (legal, scientific or technical documents) has been more frequently employed [21, 4, 20].

In this work we introduce a new literary corpus to aim the training process of algorithms focused mainly in literary text generation.

This paper is structured as follows. In Section 2 we show some works related to development and analysis of corpora. In Section 3 we describe and characterize this new corpus. Then, in Section 4 we explain some models that have used our corpus, and finally in Section 5, we propose some ideas for future works before to conclude.

\section{RELATED WORK}

The linguistic corpora have been always used for researchers in different ways [20], but recently those composed by literary documents have taken place more strongly in the NLP community. In this section we present some works where the corpora have had an important role in the research strategy.

In [25] the authors performed an analysis of English textbook series. They noticed that the frequency of vocabulary have an important impact for English students, a corpus with classified vocabulary considering the frequency of each word was proposed.

Other works addressed to the study of different languages are also found, for example, in [22] the authors constituted a parallel corpus between the French, Italian, Dutch, English and Spanish considering two specific verbal tenses: Past and Present Perfect, the idea was to compare the equivalent expression using these tenses.

In [6], an algorithm is proposed to generate biographical sentences. The model proposed use an Artificial Neural Network which has been trained with a dataset of biographies from Wikipedia in English.

Some corpora in Spanish have been built and made available to the scientific community [5]. However, a few number of them have been classified considering categories of emotions. For example the corpus SAB, composed by tweets in Spanish was introduced in [17]. The tweets represent critics toward different commercial brands. The annotation was made considering the emotion perceived for each tweet. The corpus SAB consists of 4548 annotated tweets using 8 predefined emotions: [Trust, Satisfaction, Happiness, Love, Fear, Disaffection, Sadness and Anger].

Another data set concerning tweets is the corpus TASS [23]. It contains about 70000 tweets classified using automatic methods into the following categories: [Positive, Negative, Neutral, None]. Tweets of the TASS corpus are related with different topics: Politics, Economy, Sport, Music, etc.). In [3] it is presented a global analysis (at word level) about emotion polarity. The corpus employed is composed of several lexicons in 40 languages, including Spanish. The annotation was made into the categories: [Positive and Negative].

Finally, in [16] the authors have proposed a corpus of $\approx 700$ literary sentences in Spanish. The sentences were manually annotated into the categories [Angry, Love, Sadness, Fear and Pain] by 12 persons, calculating also the agreement between them in order to assure a consistent classification. 


\section{The Megalite corpus}

We describe in this section the Literary corpus in Spanish (MegaLite). It consists in a thousand of literary documents that can be useful for automatic classification or literary text generation algorithms. The characteristic of MegaLite are also helpful for semantic or statistical analysis in NLP tasks.

The documents of MegaLite corpus come from a personal collection. For copyrights facts we are not able to distribute it in the original version. Nevertheless, we propose some alternative resources that can be used for the same purpose ${ }^{1}$. This resources have same "name_files" structures of MegaLite corpus (Section 3.1) and are described as follows:

- A set of embeddings obtained from a Word2vec model [12], using the MegaLite corpus for training (Section 3.2)

- Two versions of MegaLite corpus (Section 3.3)

1. A first version, replacing lexical words ${ }^{2}$ by the corresponding POS tags

2. A second version, replacing every word by the corresponding lemmas

- A set of tables containing n-grams frequency information (without stopwords) for each document (Section 3.4)

1. Computing unigrams and bigrams

2. Computing a version with SU4-bigrams [2]

\subsection{Corpus structure}

The MegaLite corpus was constituted using literary documents in Spanish coming from Spanishspeaking authors or using authors translations from languages other than Spanish (the full list of authors studied is available in the Annex).

This corpus was constituted by approximately 5075 documents (mainly books) in Spanish from 1336 authors. This documents belong to literary genres: plays, poems, tales, essays, etc. Due the size of this corpus, the manual quantification of genres was not possible. An automatic approach could be performed in the future.

The original documents, in heterogeneous formats ${ }^{3}$ were processed to create utf8 encoded documents.

Because of the heterogeneous of this corpus, it contains a large quantity of errors (mutilated words, strange symbols and an unusual disposition of paragraphs), these errors are usually found in corpora with similar characteristics. Also a segmentation process was performed to divide the texts into individual sentences using a tool developed in PERL 5.0 with regular expressions.

Some statistics of MegaLite corpus are detailed in Table 1.

Corpus available on the website: http://juanmanuel.torres.free.fr/corpus/megalite/

Lexical words are those containing the most important information in the text (adjectives, nouns, verbs and adverbs).

3 pdf, txt, html, doc, docx, odt, etc. 
Table 1. MegaLite corpus composed by 5075 literary works (M represents a value equals to $10^{6}$ and $\mathrm{K}$ to $\left.10^{3}\right)$.

\begin{tabular}{l|rrc}
\hline & Sentences & Tokens & Letters \\
\hline MegaLite & $15 \mathrm{M}$ & $212 \mathrm{M}$ & $1265 \mathrm{M}$ \\
\hline $\begin{array}{l}\text { Average by } \\
\text { document }\end{array}$ & $3 \mathrm{~K}$ & $41.8 \mathrm{~K}$ & $250 \mathrm{~K}$ \\
\hline
\end{tabular}

The MegaLite literary corpus has the advantage of being very extensive and suitable for automatic learning. It has, however, the disadvantage that not all sentences are necessarily literary sentences. Many of them are sentences in general language: these sentences often give a fluent reading and provide the necessary links between the ideas expressed in literary sentences. Another disadvantage of this corpus is the noise that it contains. Therefore, the process of segmentation can lead to errors in detection of sentences. Also the number of pages, chapters, sections or index produce errors. Any manual process was performed to remove this undesirable data, but as mentioned, these errors are normal in a real literary corpus containing no structured text.

The documents in the MegaLite corpus have been named with the following standardized convention: authorLastname,_authorName-workName. Then we grouped the files by author's last name. In Table 2 and 3 we present some statistics considering the regrouping performed before. For example in the first row it can be seen the information about the works from authors whom last name starts by letter 'A'.

The MegaLite corpus is suitable for testing the quality and performance of such algorithms.

Table 2. MegaLite: literary categories.

\begin{tabular}{l|c}
\hline Genre & Number of documents \\
\hline Poetic & 247 \\
Plays & 138 \\
Narrative & 4690 \\
\hline Corpus & $\mathbf{5 0 7 5}$
\end{tabular}

\subsection{Word2vec training: Embeddings}

A semantic analysis was performed with a Word2vec model [14] using Gensim ${ }^{4}$, a Python library, and the MegaLite corpus for training. The result of this process is a set of $\mathbf{4 2 0} \mathbf{7 5 7}$ embeddings. The embeddings are the numerical representation of each word inside the training corpus. Each embedding is a n-dimensional vector where the values are calculated considering the characteristics of training corpus and the different parameters established previous the training step. Each relevant word will be represented by an unique numerical vector.

4 Available in: https://pypi.org/project/gensim/ 
Table 3. MegaLite grouped by author's name.

\begin{tabular}{c|rrrrr}
\hline & Docs & Authors & Sentences & Tokens & Characters \\
\hline Anonymous & 33 & 1 & 93959 & 1634101 & 9216905 \\
A & 352 & 84 & 1174273 & 16619594 & 100024972 \\
B & 702 & 137 & 1568512 & 21225072 & 127892399 \\
C & 509 & 135 & 1476444 & 20934719 & 124866495 \\
D & 330 & 53 & 1032057 & 12726072 & 76063834 \\
E & 75 & 27 & 236646 & 3164613 & 18549948 \\
F & 94 & 39 & 325573 & 4956622 & 29488095 \\
G & 239 & 74 & 649937 & 9383297 & 56205711 \\
H & 222 & 61 & 844050 & 10941801 & 65291682 \\
I & 18 & 9 & 43934 & 733205 & 4323428 \\
J & 101 & 24 & 368267 & 5023269 & 29978644 \\
K & 161 & 29 & 639763 & 8727518 & 51278207 \\
L & 332 & 72 & 930510 & 13340874 & 79340787 \\
M & 244 & 107 & 633093 & 9165379 & 54505778 \\
N & 49 & 19 & 171528 & 2004784 & 12079194 \\
O & 32 & 16 & 98934 & 1495109 & 8880273 \\
P & 356 & 81 & 992518 & 16719626 & 97675796 \\
Q & 68 & 10 & 52451 & 702085 & 4133920 \\
R & 135 & 57 & 353089 & 5108727 & 30374508 \\
S & 489 & 150 & 1412459 & 20272228 & 120623680 \\
T & 119 & 38 & 456940 & 6468959 & 38356381 \\
U & 24 & 3 & 25761 & 414029 & 2356309 \\
V & 209 & 52 & 760585 & 11192371 & 67226725 \\
W & 123 & 34 & 418423 & 5867287 & 35242050 \\
Y & 13 & 5 & 37540 & 640867 & 3821728 \\
Z & 46 & 12 & 201073 & 2963965 & 17842523 \\
\hline Corpus & $\mathbf{5 0 7 5}$ & $\mathbf{1 3 2 8}$ & $\mathbf{1 4} \mathbf{9 9 8 , 3 1 9}$ & $\mathbf{2 1 2} \mathbf{4 2 6 , 1 7 3}$ & $\mathbf{1 2 6 5} \mathbf{6 3 9 , 9 7 2}$ \\
\hline & & & & &
\end{tabular}

In Table 4 we show the values of the following parameters: Iterations (i) refers to the number of training epochs over the MegaLite corpus. Minimal count (m) indicates the minimal number of times a word must appear in the corpus, to be included in the model's vocabulary. Vector size (s) specifies the dimension of the embeddings vectors, and Window size (w) represents the radius of adjacent words that will be related to the current word within a sentence, during the training phase of the model. We trained the model following the skip-gram approach [13], with negative sampling of five words and a down sampling threshold of 0.001 .

Table 4. Word2vec configuration parameters.

\begin{tabular}{l|c}
\hline Parameter & Values \\
\hline Iterations $(i)$ & 1 \\
Minimal count $(m)$ & 3 \\
Vector size $(s)$ & 60 \\
Window size $(w)$ & 5 \\
\hline
\end{tabular}


In Table 5 some examples of embeddings can be observed, these embeddings were obtained using three keywords, remarked in bold, also the cosine similarity between the embeddings and the keyword retrieved by the Word $2 \mathrm{vec}$ model is shown. The embeddings were translated in order to make more comprehensible the information.

Table 5. List of embeddings from queries: blue, woman and love.

\begin{tabular}{l|cc|cc|cc}
\hline Keywords & $\begin{array}{c}\text { Azul } \\
\text { (blue })\end{array}$ & $\begin{array}{c}\text { cosine } \\
\text { similarity }\end{array}$ & $\begin{array}{c}\text { Mujer } \\
\text { (woman) }\end{array}$ & $\begin{array}{c}\text { cosine } \\
\text { similarity }\end{array}$ & $\begin{array}{c}\text { Amor } \\
\text { (love })\end{array}$ & $\begin{array}{c}\text { cosine } \\
\text { similarity }\end{array}$ \\
\hline \multirow{7}{*}{ violet } & 0.934 & girl & 0.930 & hope & 0.818 \\
& green & 0.930 & old woman & 0.915 & honey & 0.805 \\
& aquamarine & 0.923 & little girl & 0.912 & delight & 0.801 \\
& purple & 0.923 & child & 0.909 & enjoy & 0.794 \\
& yellow & 0.918 & young lady & 0.900 & soul & 0.789 \\
& crimson & 0.915 & little girl & 0.892 & passion & 0.779 \\
& orange & 0.908 & maiden & 0.884 & suffering & 0.778 \\
& red & 0.908 & little old lady & 0.871 & affection & 0.776 \\
& bluish & 0.907 & little woman & 0.870 & love & 0.775 \\
& silvery & 0.901 & girl & 0.868 & desire & 0.774 \\
\hline
\end{tabular}

In the first column, it can be noticed that the keyword blue has produced embeddings like: violet, green and some other colors. Considering that the embeddings are numerical vectors, it can be concluded that numerical operations can be computed and Word2vec does it possible. So if we specify the following operation: ((['blue'] + ['ocean']) - ['violet']), the result is going to be a numerical vector, from which calculating a cosine similarity, the closest embeddings can be recovered. The Gensim library has already some functions to compute this operation, giving as result the following embeddings: sea, Pacific, Atlantic, atoll, lake, reef, Mediterranean, Arctic, Ocean, Pantanal. This is an interesting fact, because it can be observed that with the appropriated analysis, different semantic fields can be configured.

\subsection{Paralell corpora}

\subsubsection{MegaLite_POS version}

It consists in making a morph-syntactic analysis with every document in MegaLite corpus. As result, every word in each document is replaced by the corresponding POS tag. This analysis has been performed with the Freeling tool version 4.0 [18].

A POS tag offers the grammatical information concerning a determined word. A more detailed information about the POS tags can be found in the Freeling website: https://freeling-usermanual.readthedocs.io/en/latest/tagsets/. For example, in the novel "La Espada Rota" from Andersor Poul, we have the sentence: "En la obra encontrarán arcaísmos y palabras". In this sentence, Freeling returns the following analysis (Original word - POS tag):

- $\{$ “En" $\}-\{\mathbf{S P}\}=$ preposition,

- $\{$ "la" $\}-\{$ DA0FS0 $\}=$ female singular article,

- $\{$ “obra” $\}-\{$ NCFSO00 $\}=$ female singular article,

- $\quad\{$ “encontrarán" $\}-\{$ VMIF3P0 $\}=$ main verb in future tense,

- $\quad$ “arcaísmos" $\}-\{$ NCMP000 $\}=$ plural male common noun,

- $\{$ “y” $\}-\{\mathbf{C C}\}=$ connector,

- $\{$ "palabras" $\}-\{$ NCFP000 $\}=$ plural female common noun, 
- $\{$ “poco" $\}-\{\mathbf{R G}\}=$ adverb,

- $\quad\{$ "usuales" $\}-\{$ AQ0CP00 $\}=$ plural adjective and

- $\quad\{“ . "\}-\{\mathbf{F p}\}=$ punctuation remark

\subsubsection{MegaLite_lemmas version}

For the second version, every document in MegaLite corpus was processed with Freeling in order to detect the lexical words (verbs, nouns and adjectives). Then these elements were replaced by the corresponding lemmas. A lemma is the basic form of a determined word, without conjugation, in its singular form and male genre. The articles, adverbs, prepositions and the others genres out of lexical words were kept in their original form.

For example, in same sentence explained before: "En la obra encontrarán arcaísmos y palabras" the result must be: "En la OBRA ENCONTRAR ARCAÍSMO y PALABRA".

In the Table 6 below, it can be observed some sentences taken from MegaLite corpus in the different version. The sentences were taken from the work "La Espada Rota" of Andersor Poul.

Table 6. Samples of sentences recovered from the novel "La Espada Rota" of Andersor Poul in the different versions of corpora.

\begin{tabular}{|c|c|c|}
\hline Original & MegaLite_POS & MegaLite_lemmas \\
\hline $\begin{array}{l}55 \text { "Por ello, el cabo Skaw, del ex- } \\
\text { tremo norte de Jutlandia, escrito así, } \\
\text { en inglés, figura en la traducción } \\
\text { como Skagen, que es como corre- } \\
\text { sponde." }\end{array}$ & $\begin{array}{l}55 \text { Fe SP PD00S00 Fc DA0MS0 } \\
\text { NCMS000 NP00000 Fc SP } \\
\text { DA0MS0 NCMS000 NCMS000 } \\
\text { SP NP00000 Fc VMP00SM RG } \\
\text { Fc SP NCMS000 Fc VMIP3S0 SP } \\
\text { DA0FS0 NCFS000 CS NP00000 Fc } \\
\text { PR0CN00 VSIP3S0 CS VMIP3S0 } \\
\text { Fp Fe }\end{array}$ & $\begin{array}{l}55 \text { Por ello, el CABO SKAW, } \\
\text { de el EXREMO NORTE de JUT- } \\
\text { LANDIA, ESCRIBIR así, en IN- } \\
\text { GLÉS, FIGURAR en la TRADUC- } \\
\text { CIÓN como SKAGEN, que SER } \\
\text { como CORRESPONDER. }\end{array}$ \\
\hline $\begin{array}{l}56 \text { "El inglés berserk pasa a ser } \\
\text { berserkr, cuyo plural es berserkir." }\end{array}$ & $\begin{array}{l}56 \text { Fe DA0MS0 AQ0MS00 } \\
\text { NCMS000 VMIP3S0 SP VSN0000 } \\
\text { AQ0CS00 Fc PR0MS00 AQ0CS00 } \\
\text { VSIP3S0 VMN0000 Fp Fe }\end{array}$ & $\begin{array}{l}56 \text { El inglés BERSERKET PASAR } \\
\text { a SER berserkir, cuyo plural SER } \\
\text { BERSERKER }\end{array}$ \\
\hline $\begin{array}{l}57 \text { "Tarnkappe, palabra alemana que } \\
\text { Anderson ha debido tomar del Ni- } \\
\text { belungenlied, ajena, por tanto, al } \\
\text { contexto escandinavo o élfico - por } \\
\text { desgracia desconozco la lengua de } \\
\text { los elfos-, se conviene en "manto } \\
\text { de invisibilidad»." }\end{array}$ & $\begin{array}{l}57 \text { Fe NP00000 Fc } \\
\text { AQCFS000 } \\
\text { VAIP3S0 VMP00SM VMN0000 SP } \\
\text { DA0MS0 NP00000 Fc AQ0FS00 Fc } \\
\text { SP RG Fc SP DA0MS0 NCMS000 } \\
\text { AQ0MS00 CC NCMS000 Fz SP } \\
\text { NCFS000 VMIP1S0 DA0FS0 } \\
\text { NCFS000 SP DA0MP0 NCMP000 } \\
\text { Fz Fc P00CN00 VMIP3S0 SP Fra } \\
\text { NCMS000 SP NCFS000 Frc Fp Fe }\end{array}$ & $\begin{array}{l}57 \text { TARNKAPPE, PALABRA alem- } \\
\text { ana que ANDERSOR HABER DE- } \\
\text { BER TOMAR del NIBELUNGEN- } \\
\text { LIED, ajena, por tanto, al CON- } \\
\text { TEXTO escandinavo o ÉLFICO por } \\
\text { DESGRACIA DESCONOCER la } \\
\text { LENGUA de los ELFO-, se CON- } \\
\text { VENIR en «MANTO DE INVISI- } \\
\text { BILIDAD» }\end{array}$ \\
\hline $\begin{array}{l}58 \text { "Eochy, uno de los apelativos del } \\
\text { dios irlandés Dagda, escrito así al } \\
\text { transcribirlo al inglés, ha sido ree- } \\
\text { scrito como Echu, en gaélico." }\end{array}$ & $\begin{array}{l}58 \text { Fe NP00000 Fc PI0MS00 SP } \\
\text { DA0MP0 NCMP000 SP DA0MS0 } \\
\text { NCMS000 AQ0MS00 NP00000 } \\
\text { Fc VMP00SM RG SP DA0MS0 } \\
\text { VMN0000 PP3MSA0 SP DA0MS0 } \\
\text { NCMS000 Fc VAIP3S0 VSP00SM } \\
\text { VMP00SM CS NP00000 Fc SP } \\
\text { NCMS000 Fp Fe }\end{array}$ & $\begin{array}{l}58 \text { EOCHY, uno de los APELA- } \\
\text { TIVO de el DIOS irlandés DAGDA, } \\
\text { ESCRIBIR así a el TRANSCRIBIR } \\
\text { lo a el INGLÉS, HABER SER } \\
\text { REESCRIBIR como ECHU, en } \\
\text { GAÉLICO. }\end{array}$ \\
\hline $\begin{array}{l}59 \text { "En la obra encontrarán arcaís- } \\
\text { mos y palabras poco usuales." }\end{array}$ & $\begin{array}{l}59 \mathrm{Fe} \text { SP DA0FS0 NCFS000 } \\
\text { VMIF3P0 NCMP000 CC NCFP000 } \\
\text { RG AQ0CP00 Fp Fe }\end{array}$ & $\begin{array}{l}59 \text { En la OBRA ENCONTRAR } \\
\text { ARCAÍSMO y PALABRA poco } \\
\text { usuales. }\end{array}$ \\
\hline
\end{tabular}




\section{4. n-grams statistics}

We also compute the frequency of unigrams, bigrams and Skip grams (SU4) bigrams. For bigrams, every pair of word on each document was computed. A table with the bigrams frequency for document was composed after this process. For SU4-bigrams we considered the frequency of every pair of words, to compose these pairs, we take a word and then we skip the following $n=1, \ldots, 4$ words, joining the next word. For example, for the sentence: The kids are playing in the garden, we can compose the following SU4-bigrams: [The-kids, The-are, Theplaying, The-in, kids-are, kids-playing, kids-in, kids-the, are-playing, are-in, are-..., ...-...].

A sample of five bigrams and SU4-bigrams with major frequency extracted from four works in MegaLite corpus are displayed in Table 7.

Table 7. n-grams frequency from MegaLite corpus.

\begin{tabular}{|c|c|c|c|}
\hline Bigrams & frequency & SU4-bigrams & frequency \\
\hline \multicolumn{4}{|c|}{ Dahl,_Roal-El_gran_cambiazo } \\
\hline —dijo jerry & 16 & —dijo jerry & 16 \\
\hline labio inferior & 13 & — dijo jerry- & 13 \\
\hline —dijo jerry- & 13 & labio inferior & 13 \\
\hline —preguntó jerry & 7 & -no - dijo & 7 \\
\hline boquete seto & 6 & —preguntó jerry & 7 \\
\hline \multicolumn{4}{|c|}{ Abbot,_Edwing_A-Planilandia } \\
\hline linea recta & 40 & línea recta & 42 \\
\hline tres dimensiones & 26 & tres dimensiones & 27 \\
\hline identificación visual & 16 & identificación visual & 16 \\
\hline tercera dimensión & 14 & tercera dimensión & 14 \\
\hline proyecto ley & 13 & nueve centímetros & 13 \\
\hline \multicolumn{4}{|c|}{ Baar,_Robert-La_ruina_de_Londres } \\
\hline sir john & 23 & sir john & 23 \\
\hline siglo xix & 6 & siglo xix & 6 \\
\hline cannon street & 6 & cannon street & 6 \\
\hline gente siglo & 4 & oficina sir & 5 \\
\hline oficina sir & 4 & gente siglo & 4 \\
\hline \multicolumn{4}{|c|}{ Caballero,_Fernan-Cosa_cumplida } \\
\hline prosiguió marquesa & 12 & conde marquesa & 20 \\
\hline dos cuartos & 10 & marquesa conde & 18 \\
\hline repuso conde & 9 & prosiguió marquesa & 12 \\
\hline repuso marquesa & 9 & repuso conde & 11 \\
\hline marquesa alora & 8 & dos cuartos & 10 \\
\hline
\end{tabular}

\section{IMPLEMENTATIONS}

In this section we will discuss some works that have used the MegaLite corpus to perform their experiments.

The works described below, belong to the same project, in which the authors have proposed new approaches and improvements. In all cases they used a Word2vec model for semantic analysis, the training of these models were done using an earlier version of the MegaLite corpus, called $5 \mathrm{KL}$ corpus. The $5 \mathrm{KL}$ corpus contains almost the same literary works as the MegaLite corpus, 
but with the disadvantage that it also contains many non-literary texts. The MegaLite corpus has been filtered out of those non-literary texts and has also been enriched with more literary texts.

Text generation with context: In the work described in [9] a model for the generation of literary sentences is proposed. Three different experiments were carried out applying stochastic methods, Markov chains and methods based on Canned Text [15] for text generation. These methods were trained using an old version of MegaLite corpus called 5KL corpus.

For each experiment, a manual evaluation was performed. Being the method based on Canned Text the best scored, a general schema of this model can be observed in 1. For evaluation three criteria were considered: coherence, grammar and context-related.

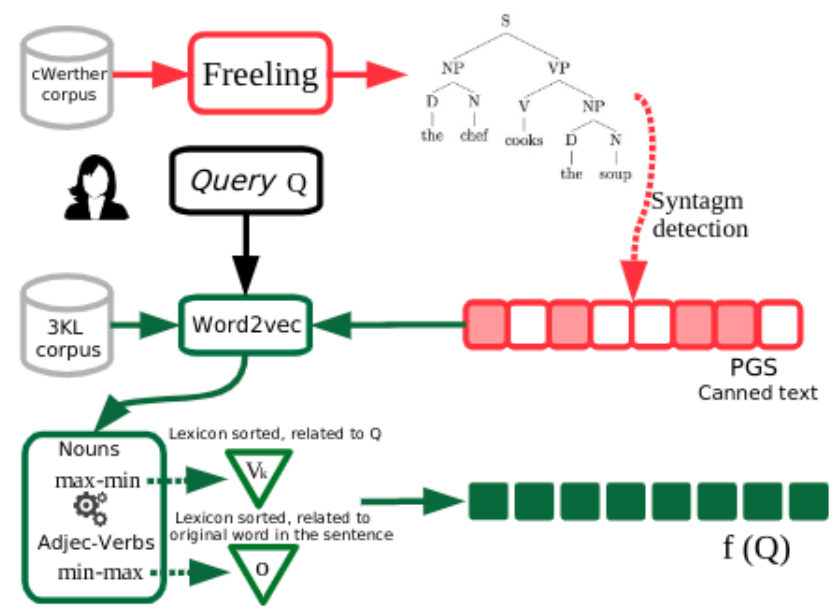

Figure 1. Automatic text generation model

Text generation using emotions: The work [7] is an extension of the experiments carried out in [9] where besided MegaLite corpus, others linguistic tools were imployed. In this work, the authors propose a new schema for manipulating the semantic relation between several queries through the calculation of cosine similarities among the embeddings recovered from the Word2vec model.

The new proposal was evaluated manually by seven persons, getting the following scores into a rank from 0 to 1 . For grammar: 0.77 , coherence: 0.60 and context: 0.53 .

Text generation with personality traits: In [8], the authors considered the proposal in [7] and then added new elements to generate text replicating the linguistic styles associated with personality. For example, a negative personality could present cases where words such as woman and hate are found within a very narrow semantic field; while a positive personality could relate woman to beauty or sensuality.

Again, the MegaLite corpus was used to train the Word2vec model, but in addition, the authors considered two sets of new corpora and fed them with works from two authors with different and easily identifiable personalities: Johann Wolfgang von Goethe and Edgar Allan Poe. The text generated was evaluated manually, the criteria to be evaluated were the same as in the previous works with equally correct results. But additionally the evaluators specified the emotions that they perceived from the generated texts, the results were interesting, especially for the texts generated from Goethe's corpus, where the emotions are very similar 
to those expressed by Goethe in his work "The Sorrows of Young Werther". In Figure 2 we can see the distribution of emotion perceived in the generated texts.

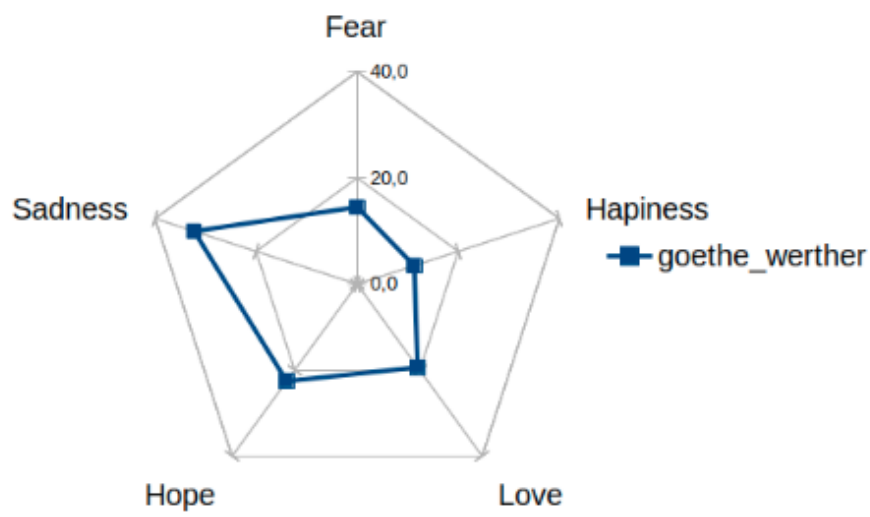

Figure 2. Perceived emotions in sentences generated from Goethe's corpus

\section{CONClusions ANd Future Works}

In this article we introduce MegaLite, a new literary corpus composed of literary works having homogeneous genres. MegaLite has the right dimensions to be used in learning tasks and eventually it could be segmented to perform also a validation process for generative or classification algorithms in Natural Language Processing.

The works mentioned in the section 4 show that MegaLite is a very suitable corpus with enough literary documents to be used in Computational Creativity tasks and more specifically in the literary domain.

\subsection{Advantages and limitations}

We could remark some advantages of using our corpus, firstly the adequate size, with an important number of literary documents. Also that all documents were consciously filtered in order to keep only the literary ones. The variety in the vocabulary, due to the documents are not closed to an specific genre or period, this allows to perform a more extended linguistic analysis.

Nevertheless, some disadvantages were also detected when using the MegaLite corpus. For example, some oldest documents are written with an ancient vocabulary and the computational tools cannot process it. Also, if the objective is to perform an analysis of writing style, the MegaLite corpus has the inconvenient that an important number of documents have been translate from other languages, even if we carefully selected the documents from reliable sources, it exists always an alteration when a literary work is translated to another language.

The works that compose the MegaLite corpus belong to a private collection and due to copyright issues they cannot be distributed in their original format. Therefore, we make available two parallel versions 3, which can be used for statistical and morphological analysis or for training of language models. 


\subsection{Future works}

This resource is intended to be a free and open corpus for the scientific community. New versions with a larger number of documents, particularly belonging to the genres of poetry and theater, will be available in the future.

Two deeper analyses are also planned on this corpus: the first one is to classify the documents into different genres and periods, and the second one is to study and identify the most important rhetorical structures in the documents [5, 26].

Finally, we want to increase the MegaLite corpus, by creating new corpora with the same characteristics in other languages, such as Portuguese and French.

\section{ACKNOWLEDGEMENTS}

This work is funded by Consejo Nacional de Ciencia y Tecnología (Conacyt, Mexico), grant number 661101 and partially by the Université d'Avignon/LIA, France.

\section{REFERENCES}

[1] Margaret A Boden.The creative mind: Myths and Mechanisms. Routledge, 2004.

[2] Luis Adrián Cabrera-Diego and Juan-Manuel Torres-Moreno. Summtriver: A new trivergent model to evaluate summaries automatically without human references. Data Knowledge Engineering, 113:184-197, 2018.

[3] Yanqing Chen and Steven Skiena. Building sentiment lexicons for all major languages. In $52^{\text {nd }}$ Annual Meeting of the ACL, volume 2, pages 383-389, 2014.

[4] Iria da Cunha, M. Teresa Cabré, Eric SanJuan, Gerardo Sierra, Juan-Manuel Torres-Moreno, and Jorge Vivaldi. Automatic specialized vs. non-specialized sentence differentiation. InCICLing, pages 266-276, 2011.

[5] Iria da Cunha, Juan-Manuel Torres-Moreno, and Gerardo Sierra. On the development of the RST spanish treebank. In Fifth Linguistic Annotation Workshop, LAW2011, June 23-24, 2011, Portland, Oregon, USA, pages 1-10. The Association for Computer Linguistics, 2011.

[6] Rémi Lebret, David Grangier, and Michael Auli. Neural text generation from structured data with application to the biography domain. Preprint arXiv:1603.07771, 2016.

[7] Moreno-Jiménez Luis-Gil, Torres-Moreno Juan-Manuel, and Wedemann Roseli. Generación de frases literarias: un experimento preliminar. In $36^{\text {th }}$ Annual SEPLN Congres. SEPLN, 2020. Accepted.

[8] Moreno-Jiménez Luis-Gil, Torres-Moreno Juan-Manuel, and Wedemann Roseli. Literary natural language generation with psychological traits. In $25^{\text {th }}$ International Conference on Natural Language and Information Systems. NLDB, 2020.

[9] Moreno-Jiménez Luis-Gil, Torres-Moreno Juan-Manuel, Wedemann Roseli, and Eric SanJuan. Generación automática de frases literarias. Linguamática, 12(1):15-30, 2020.

[10] Jeffrey Masten, Peter Stally brass, and Nancy J Vickers. Language machines: technologies of literary and cultural production. Routledge, 2016.

[11] Salah Mejri. Les trois fonctions primaires. Une approche systématique. de la congruence et de la fixité dans le langage. In De la langue à l'expression: le parcours de l'expérience discursive. Hommage à Marina Aragón Cobo, pages 123-144. Servicio de Publicaciones, 2017.

[12] T. Mikolov and G. Zweig. Context dependent recurrent neural network language model. In 2012 IEEE Spoken Language Technology Workshop (SLT), pages 234-239, Dec 2012.

[13] Tomas Mikolov, Kai Chen, Greg Corrado, and Jeffrey Dean. Efficient estimation of word representations in vector space. In Yoshua Bengio and Yann Le Cun, editors,1st International Conference on Learning Representations, Scottsdale, Arizona, USA, 2013. ICLR.

[14] Tomas Mikolov, Wen-tau Yih, and Geoffrey Zweig. Linguistic regularities in continuous space word representations. In North American Chapter of the ACL: Human Language Technologies, pages 746-751, 2013. 
[15] Paul Molins and Guy Lapalme. Jsrealb: A bilingual text realizer for web programming. In $15^{\text {th }}$ European Workshop on Natural Language Generation (ENLG), pages 109-111, 2015.

[16] Luis-Gil Moreno-Jiménez and Juan-Manuel Torres-Moreno. Lisss: A new multi-annotated multiemotion corpus of literary spanish sentences. Computación Sistemas, 24:1139-1147, 2020.

[17] M. Navas-Loro, V. Rodríguez-Doncel, I. Santana-Pérez, and A. Sánchez. Spanish corpus for sentiment analysis to wards brands. In International Conference on Speech and Computer, pages 680689, 2017.

[18] Luís Padró and Evgeny Stanilovsky. Freeling 3.0: Towards wider multilinguality. In LREC2012, 2012.

[19] R.P. Pérez. Creatividad Computacional. El Libro Catedra. Larousse - Grupo Editorial Patria, 2015.

[20] Gerardo Sierra. Introducción a los Corpus Lingüísticos. UNAM Mexico., 2018.

[21] Juan-Manuel Torres-Moreno. Automatic Text Summarization. Wiley, London, 2014.

[22] Martijn Van der Klis, Bert Le Bruyn, and Henriëtte de Swart. A multilingual corpus study of the competition between past and perfect in narrative discourse. Ms., 2020.

[23] Julio Villena-Román, Sara Lana-Serrano, Eugenio Martínez-Cámara, and José Carlos GonzálezCristóbal. Tass -workshop on sentiment analysis at sepln. Procesamiento del Lenguaje Natural, 50(0):37-44, 2013.

[24] Noah Wardrip-Fruin. Digital media archaeology: Interpreting computational processes. Media archaeology: Approaches, applications and implications, pages 302-322, 2011.

[25] Lu Yang and Averil Coxhead. A corpus-based study of vocabulary in the new concept english textbook series. RELC Journal, doi.org/10.1177/0033688220964162, 2020.

[26] Maite Taboada, and William C. Mann. 2006b. Applications of Rhetorical Structure Theory. Discourse Studies, 8(4):567-588.

\section{AUTHORS}

Luis-Gil Moreno-Jiménez: Doctoral researcher in computer science at the LIA of the University of Avignon, France with the thesis "Computational Creativity: generation of literary sentences". Master's degree in Computer Engineering from the Center for Research and Technological Development (Mexico), in the field of Automatic Classification and Recognition of Named Entities. He is the co-author of 12 published scientific articles and 1 in the process of appearing.

Juan-Manuel Torres-Moreno: Senior lecturer HDR in Computer Science at the University of Avignon, France. Researcher at the Avignon Computer Science Laboratory (LIA). His area of expertise is at the intersection of Automatic Language Processing and Machine Learning. He is author of the books "Automatic Text Summarization" Wiley 2014, "Automatic Text Summarization: A Statistical Approach" and "Introduction to Operating Systems", in addition to being co-author of approximately 200 scientific papers.

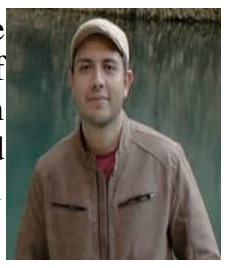

\section{AnNex: Author listing Of MegaLite}

Abbott, Edwin A; Abernathy, Robert; Adams Caridad Bravo; Adams, Douglas; Adrian, Luis R; Afanasiev, Aleksandr Nikolaevich; Agudo, Enrique; Aguilar, Hector; Aguilar, Joao de; Aguilera, Juan Miguel; Ahon, Jorge; Akutagawa, Ryunosuke; Alarcon, Pedro Antonio de; Alas Clarin, Leopoldo; Alberti Rafael,; Alcott, Louisa May; Aldiss, Brian W; Alexander, Lloyd; Alighieri, Dante; Ali, Tariq; Alkalay Gut, Karen; Allen DeFord, Miriam; Allende, Isabel; Allen, Grant; Alonso, Damaso; Alonso, Jesus; Alper, Gerald Arthur; Alsuna Rodrigo; Altamirano, Ignacio Manuel; Altamirano Jose; Altolaguirre, Manuel; Alvarez, Blanca; Alvarez, Gardeazabal; Alvarez Villar alfonso; Amado, Jorge; Amador de los Rios, Rodrigo; Ambler Eric; Ambort, Monica; Amicis, Edmundo de; Amis, Martin; Ammons, A.R; Ananda; Andersen, Hans Christian; Anderson Imbert, Enrique; Anderson, Poul; Andrade Olegario V; Angel de Saavedra; Anthony, Piers; Anvil, Christopher; Apollinaire, Guillaume; Appell, Claude; Apuleyo Lucio; Arango Angel; Arevalo Martinez, Rafael; Arguedas, Alcides; Aristofanes; Arlt, Roberto; Arniches, Carlos; Arnold, H. F; Aroca, Jose Maria; Arreola, Juan Jose; Arsenal, Leon; Artaud, Antonin; 
Asensi, Julia de; Ashley, Michael; Ashton Smith, Clark; Asimov, Isaac; Asquerino, Eduardo; Asselineau, Charles; Atherton, Gertrude; Atienza, Juan G; Attanasio, Alfred A; Atulananda, Srila; Atwood, Margaret; Aub, Max; Aubourg Dejean Raymond, Fracois; Auel, Jean M; Auguste de Chateaubriand, Francois; Austen, Jane; Auster, Paul; Avila, Gaspar de; Axpe Loisa; AnonimAnonimo; Baar, Robert; Bachman, Richard; Bach, Richard; Bacon, Francis; Bagnasco, Oracio; Bahamon Dussan, Mario; Ballard, J. G; Balzac, Honore De; Banks, Iain M; Banks, Raymond E; Barcelo, Elia; Barclay, Alan; Baricco, Alessandro; Barjavel, Rene; Barker, Clive; Baroja, Pio; Barranco Ibarbia, Sergio; Barreto Burgos, Chiquita; Barrie, J.M; Barrows, Dunham; Basadre y Chocano, Modesto; Bass, T. J; Bates, Harry; Baudelaire, Charles; Baum, Lyman; Baxter, Stephen; Bayley, Barrington J; Bayly, Jaime; Beagle, Peter; Beam, Piper H; Bear, Greg; Beauvoir, Simone de; Beckett, Samuel; Becquer, Gustavo Adolfo; Behm, Marc; Belen; Beletzky, Alejandro; Beliaev, Alexander; Belknap Long, Frank; Bellegarrigue, Anselmo; Belli, Gioconda; Bello, Andres; Belmonte Bermudez, Luis; Benavente, Jacinto; Benedetti, Mario; Benet, Juan; Benet, Stephen V; Benford, Gregory; Benigni, Roberto; Benitez, J.J; Benson, E. F; Bentine, Michael; Beramendi, Luis; Bergdolr, Ute; Bergerac, Cyrano de; Berger, John; Bergier, Jacques; Berlitz, Charles; Bermejo Martinez, Ignacio; Bester, Alfred; Beverly, Jo; Bierce, Ambrose; Biggle, Lloyd Jr; Bilbao, Luis; Bioy Casares, Adolfo; Biscay, Acarette; Bishop, Michael; Bisson, Michael; Bisson, Terry; Black, Bob; Blackwood, Algernon; Blaisten, Isidoro; Blake, William; Blanco, Eloy; Blanco, Juan Ignacio; Blanco White, Jose Maria; Blasco Ibanez, Vicente; Blatty, William P; Blest Gana, Alberto; Blish, James; Blissett, Luther; Bloch, Robert; Boccaccio, Giovanni; Boix, Armando; Boll, Heinrich; Bond, Nelson; Bone, J.F; Bonfico, Luciano; Borges, Jorge Luis; Bornemann, Elsa; Boto Bravo, Jose Maria; Boucher, Anthony; Boulgakov, Mikhail; Boulle, Pierre; Bourdieu, P; Bova, Ben; Boyd, John; Brackett, Leigh; Bradbury, Ray; Braddon, Mary Elizabeth; Bravo Adams, Caridad; Bravo, Jose Maria; Breton, Andre; Bridge, Ann; Brin, David; Brindisi, Mauro; Brite, Poppy Z; Brolio, Roberto; Bronte, Charlotte; Bronte, Emily; Brown, Dan; Brown, Eric; Brown, Fredric; Browning, Robert; Brown, Sandra; Bruch, Gabriela; Brunner, John; Brust, Stephen; Bryant, Edward; Bryce Echenique, Alfredo; Bucay, George; Bucheli, E; Buda; Budge, W; Budrys, Algis; Bujold, Lois McMaster; Bukowski, Charles; Bunch, David R; Burckhardt, Titus; Burgess, Anthony; Burgos, Carmen de; Burns, Ron; Burroughs, Edgar Rice; Busbee, Shirlee; Butler, Octavia; Buzzati, Dino; Byron, Lord; Caballero, Fernan; Cabeza de Vaca, Alvarez Nunez; Cabrera Infante, Guillermo; Cabrera, Lydia; Cain, James; Calderon de la Barca; Calin, P. G. M; Calvino, Italo; Calvo Macias, Roberto; Camarero, Oscar; Camoens, Luis de; Campbell, John W; Campbell, J. Ramsey; Camp, L. Sprague de; Campoamor, Ramon de; Campo, Estanislao del; Camus, Albert; Canalda, Jose Carlos; Cane, Miguel; Cano, Dorian; Caparros, Martin; Capek, Karel y Joseph; Capote, Truman; Caraccioli, Louis Antonie de; Card, Scott Orson; Carey, Diane; Carletti, Eduardo J; Carmen Tapia, Maria del; Caro de Mallen, Ana; Carpentier, Alejo; Carr, Charles; Carriego, Evaristo; Carrol, Lewis; Carr, Terry; Carsac, Francis; Carter, Angela; Carter, Lin; Casanova, Giacomo; Casa, Ricardo de la; Casas, Bartolome de las; Castelman, Rafael; Castillo, Abelardo; Castresana, Luis de; Castro, Fidel; Castro, Guillen de; Castro, Rosalia de; Catulo; Cavafis, Constantino P; Cayo Salustio Cripo; Cazorla Artieda, Diego; Cela, Camilo Jose; Celaya, Gabriel; Cercas, Javier; Ceron Lopez, Rosa G; Cervantes Saavedra, Miguel de; Cesar, Cayo Julio; Chambers, Robert W; Chancel, Rosa; Chandler, AB; Chandler, Raymond; Chandra, C.K; Chase, James Hadley; Chaucer, Geoffrey; Chaucer, Godfred; Chejov, Anton; Cherry, C J; Chesterton; Chretien de Troyes; Christie, Agatha; Chumacero, Ali; Chumez, Chumy; Cibilis Mabel, Pedrozo; Ciceron, Tulio Cayo; Cilento, Elena; Cioran, E. M; Cisneros, Luis Benjamin; Clancy, Tom; Clareson, Thomas D; Clarin, Leopoldo Alas; Clarke, Arthur C; Clarke, Arthur C; Clarke, Arthur C. y Gentry Lee; Clarke, Arthur C. y Paul Preuss; Clausewitz, Karl von; Clavell, James; Clay Estrada, Rita; Clement, Hal; Clingermann, Mildre; Cobb, Humphrey; Coelho, Paulo; Colby, Robert; Coleridge, Samuel Taylor; Collins, Wilkie; Collodi, Carlo; Cologne, Daniel; Coloma, Luis; Colon, Cristobal; Colt, Emma; Comet, Alan; Comite invisible; Comuniello, Sofia; Conan Doyle, Sir Arthur; Conde, Carmen; Conelly, Michael; Conolly, Lawrence; Conrad, Joseph; Contoski, Victor; Conway, Gerard F; Cook, 
Robin; Cooper, Edmund; Cooper, Louise; Copland, Aaron; Coppel, Alfred; Cormoran, Vicente Segismundo; Cornwell, Patricia D; Coronado, Carolina; Coronel Ignotus; Correa, Hugo; Cortazar, Julio; Cortese, Abel; Cotrina, J. A; Coue, Emile; Covadonga, Maria; Cram, Raph Adam; Crawford, F. M; Crichton, Michael; Crowe, Catherine; Crowley, John; Cruz, Carles de la; Cruz, San Juan de la; Cuesta Marin, Antonio; Cummings, Ray; Cunha, Fausto; Cussler, Clive; Czajkowski, Hania; Dahl, Roal; Dahl, Roald; Daireaux, Godofredo; Daley, Brian; Dali, Salvador; Daniels, Williams; Dario, Ruben; Daudet, Alfonso; Davidson, Avram; Da Vinci, Leonardo; De Amalfi, Gunter; Dean Foster, Alan; De Ercilla, Alonso; Defoe, Daniel; De Jesus, Sor Maria; De Laclos, Choderlos; De la Cruz, Sor Juana Ines; Delany, Samuel; De la Puente, Eduardo; De las Casas, Bartolome; Delibes, Miguel; Del Rey, Lester; Denevi, Marco; De Pedrolo, Manuel; De Quincey, Thomas; Derleth, August; Descartes, Rene; Desproges, Pierre; Deutsch, A. J; Deveraux, Jude; Dias Garcia, Eulogio; Diaspar; Diaz del Castillo, Bernal; Diaz Perez, Rodrigo; Diaz Rodriguez, Manuel; Diaz Sanchez, A; Dickens, Charles; Dickens Charles; Dick, Philip K; Dickson, Gordon R; Diego, Gerardo; Dieterich Steffan, Heinz; Disch, Thomas M; Disney, Walt; Dneprov, Anatoli; Dolina, Alejandro; Donoso, Jose; Dorfman, Ariel; Dostoyesvski, Fedor; Downing, Christine; Druon, Maurice; Dumas, Alejandro; Dunsany, Lord; Eca de Queiroz, Jose Maria; Echegaray, Jose; Echeverria, Esteban; Eco, Umberto; Eddings, David; Eddison, Eric Rucker; Edmonson, G. C; Edwadrs, Jorge; Effinger, George A; Egan, Greg; Eliot, George; Eliot, T.S; Ellin, Stanley; Elliot, Bruce; Ellison, Harlan; Ende, Michael; Erasmo de Rotterdam; Ercilla y Zuniga, Alonso de; Erckmann Chatrian; Escamilla, Pedro; Esopo; Espronceda, Jose de; Esquivel, Laura; Estacio, Publio Papinio; Euripides; Evanovich, Janet; Valera, Juan; Fallaci, Oriana; Fante, John; Farber, Sharon N; Farmer, Philip J; Fast, Howard; Faulkner, William; Feijoo, Fr. Benito J; Felipe, Leon; Fenelon, Francois; Ferman, Edward L; Fernandez Arguelles, Jose Manuel; Fernandez Benayas, Antonio; Fernandez de Lizardi, Jose Joaquin; Fernandez de Moratin, Leandro; Fernan Gomez, Fernando; Ferran, Augusto; Fetjaine, Jean Louis; Feuchtwanger, Lion; Fielding, Helen; Filer, B. K; Finney, Charles G; Fisher, Robert; Fitzgerald , Francis Scott; Flaubert, Gustave; Floppa, Alaide; Flores Chavez, Jaime Alonso; Follett, Ken; Fontanarrosa, Roberto; Forbes, John; Ford, John M; Forsyth, Frederick; Forward, Robert L; Foster, Alan Dean; France, Anatole; Frank, Ana; Frazer, James G; Fripp, Anderson; Fuentes, Carlos; Fuertes, Gloria; Gache, Belen; Gaiman, Neil; Gaite, Carmen Martin; Gala, Antonio; Galeano, Eduardo; Galilei, Galileo; Galofre, R; Galouye, Daniel F; Gandhi, Mahatma; Gandolfo, Elvio E; Garaudy, Roger; Garcia Lorca, Federico; Garcia Marquez, Gabriel; Garcia Montero, Luis; Garcia Pavon, Francisco; Garcia Rey, Pepe; Garci, Jose Luis; Gardini, Carlos; Gardner, Erle Stanley; Garland, Curtis; Garro, Elena; Garro, Helena Paz; Gasco, Mila; Gatti, Attilio; Gaudichaud, Franck; Gautier, Theophile; Gedge, Pauline; Geier, Chester S; Genet, Jean; Gerritsen, Tess; Gibran, Khalil; Gibson, William; Gilden, Mel; Gilien, Sasha; Gil, Martin; Gisbert, Joan Manuel; Glassier, Alice; Godwin, Tom; Goethe; Gogol, Nicolai V; Golding, William; Goldstein, Lisa; Goligorsky, Eduardo; Gomez Saafigueroa, Hilario; Gomez, Ubaldo; Gongora, Luis de; Gonzalez Vera, Jose Santos; Gordon, Noah; Gorki, Maximo; Gorodischer, Angelica; Gorostiza, Jose; Graham, Lynne; Grass, Gunter; Graves, Anthony; Graves, Robert; Greenberg , Martin H; Greene, Graham; Greenland, Colin; Green, Peter; Greg, Edgan; Grey, Zane; Grimwood, Ken; Gripari, Pierre; Grisham, John; Guareschi; Guevara, Ernesto Che; Guillen de Castro; Guillen, Jorge; Guinevere, Queen; Guin, Wyman; Guiraldes, Ricardo; Gunn, James E; Guy de Maupassant; Guzman, Martin Luis; Hagakure; Haggard, Henry R; Haiblum, Isidore; Haig, John; Haldeman, Joe; Hamilton, Edmond; Hammett, Dashiell; Hardy, Thomas; Harichandra; Harness, Charles L; Harrison, Harry; Harris, Thomas; Harris , Thomas; Hartman, Gaut Vel; Hawking, Stephen; Hearn, Lafcadio; Hebel, Johann Peter; Heinink y Dickson; Heinlein, Robert A; Hemingway, Ernest; Henderson, Zenna; Herbert, Frank; Herbert, James; Hermanos Grimm; Hermes Trismegisto; Hernandez, Jose; Hernandez, Jose L; Hernandez, Miguel; Hernun; Herodoto; Heron, H and E; Hesse, Hermann; Hettche, Thomas; High,P.E; Hipocrates; Hitler, Adolf; Hoffmann Price, E; Hofstaedter, Dougas; Hogdson, William H; Holdstock, Robert; Hollis, H. H; Holmes, Elisabeth; Homero; Hopkins,Brian; Horacio; Horacio, Quinto; Horkheimer; Houellebecq, Michel; Hougron, 
Jean; Howard, Robert E; Howard, W; Hoyle, Fred; Hubbard, P. M; Hugo, Victor; Huidobro, Vicente; Huidobro, Vocente; Hume, David; Hunichiro, Tanizaki; Hunter, James; Hurtado de Mendoza, Antonio; Huxley, Aldous; Ibarguengoitia, Jorge; Ignotus, Coronel; Infante de Castilla Juan Manuel; Ingenieros, Jose; Iriarte, Tomas de; Irish, William; Isaacs, Jorge; Ishiguro, Kazuo; Ivan S. Turgueniev; Jackson, Clive; Jacobs, W W; Jacq, Christian; Jakubowski, Maxim; James, E.L; James, Henry; James, Montague Rhode; Jardiel Poncela, Enrique; Jarry, Alfred; Jenkins, W F; Jennings, G; Jerome, K; Jimenez, Juan Ramon; Jodorowsky, Alejandro; Jokai, Mor; Joly, Maurice; Jones, Alice; Jones, James; Josefo, Flavio; Joseph, Tim; Joyce, James; Juarroz, Roberto; Judd, Cyril; Jung, Carl Gustav; Kafka, Franz; Kaku, Michio; Kaplan, Nelly; Kapp, Colin; Kapra, Peter; Katayama, Kyoichi; Kay, Guy Gavriel; Kazuo, Ishiguro; Keeler, Harry Stephen; Kelly, James Patrick; Kennedy Toole, John; Kessel, John; Kierkegaard, Soren; King, Stephen; Kipling, Rudyard; Kippax, John; Knight, Damon; Koch, Howard; Koestler, Arthur; Kohan, Nestor; Koontz, Dean R; Kornbluth, C. M; Kosinsky, Jerzy; Krentz, Jayne Ann; Krishnamurti, J; Kube; Kundera, Milan; Kushner, Ellen; Kuttner, Henry; Laercio, Diogenes; Laferrere, Gregorio de; Lafferty, Raphael A; Lake, David; Lanata, Jorge; Landis, Geoffrey; Langelaan, George; Langford, David; Lao Tse; Larra, Mariano Jose de; Lasswitz, Kurd; Latorre, Mariano; Laumer, Keith; Laureano, Ernesto; Laurence J., Peter; Lautreamont; Lavin, Eric; Lawhead, Stephen; Lawrence, D.H; Lazarte, Rolando; Leakey, Richard; Lederman, Leon; Lee, Carrol; Lee, Tanith; Le Guin, ursula K; Le Guin, Ursula K; Leiber, Fritz; Leibniz, Godfred; Leigh Bromley, Gordon; Leinster, Murray; Lem, Stanislaw; Lengyel, Olga; Lenley, Brad; Leon, Fray Luis de; Leoux, Gaston; Levin, Ira; Levrero, Mario; Lewis, C. S; Lewis, Roy; Lieber, Fritz; Lightman, Alan; Lillo, Baldomero; Limonche Valverde, Francisco; Linares, Alfonso; Lindo, Elvira; Lindsey, Johanna; Lispector, Clarice; Lloyd, Alexander; Lloyd Biggle, Jr; Lloyd Castle, Jeffery; Llull, Ramon; Lobsang Rampa, T; Lohoff, Ernst; Lois McMaster Bujold; London, Jack; Loomis, Noel; Lope de Vega; Lopez de Gomara, Francisco; Lopez de Yanguas, Hernando; Lopez, Lucio V; Lopez Rivera, Rafael; Lord Dunsany; Lorenz, Konrad; Lovecraft, H. P; Lowry, Malcom; Luca de Tena, Torcuato; Lucas, George; Lukodianov, Isai; Lulio, Raimundo; Lumley, Brian; Lynn, Elizabeth A; Lyra, Carmen; MacCaffey, Anne; Machado, Antonio; Machen, Arthur; Mackenzie, Ann; Maeterlinck, Maurice; Mahfuz, Naguib; Mahoma; Malzberg, Barry N; Manasse de Numenor; Mandino, Og; Mandrazo, Pedro de; Mann, Thomas; Manrique, Jorge; Mansilla, Eduarda; Marcos, Jose Maria; Marcos, Subcommandante + Paco Ignacio Taibo II; Mares; Marino, Juan; Marin Trechera, Rafael; Marse, Juan; Marti, Jose; Martinez de la Rosa, Francisco; Martinez Estrada, Ezequiel; Martinez Garrido, Alfonso; Martinez Heredia, Fenando; Martinez, Raymond J; Martinez, Tomas Eloy; Martin, George R.R; Martin, George R.R+Tuttle, Lisa; Martin Gil; Martin Mora, Angel Campos; Martinov, Gueorgui; Martin Santos, Luis; Marti, Vicente; Marx, Groucho; Marx, Karl; Masliash, Leo; Masso, Gustavo; Mastretta, Angeles; Matheson, Richard; Matus Acuna, Alejandra; Matute, Ana Maria; Maugham, W. Somerset; Maupassant, Guy de; Maxwell, Megan; Mc Caffrey, Anne; McCloud, Richard; McDonald, Ian; Mcintosh, J. I; McKiernan, Dennis L; Mclaren, John; Mclntyre, Vonda N; McMaster Bujold, Lois; Medina, Jose Toribio; Meik, Vivian; Melville, Herman; Mendoza, Eduardo; Mercader, Martha; Merek, Sahu Ari; Merritt, Abraham; Mesonero Romanos, Ramon de; Meyrink, Gustav; Miezza, Juan I; Miguel, Julio de; Miller, Henry; Miller, Lion; Miller, Walter M; Mill, John Stuart; Millman, Dan; Milton, John; M intosh, J. I; Mira de Amescua, Antonio; Mishima, Yukio; Mistral, Gabriela; Mitre, Bartolome; Mocho, Fray; Moix, Terenci; Moliere; Molina, Tirso de; Moncada, Francisco de; Monsivais, Carlos; Montague, T J; Monteleone, Thomas F; Monterroso, Augusto; Montes, Raphael Nieto; Moorcock, Michael; Moorcook, Michael; Moore, Michael; Moore, Robert; Moore, Ward; Mora, Juan de Dios; Morel, Fran; Moro, Juan; Moro, Tomas; Morrison, Jim; Moskowitz, Sam; Moujan Otano, Magdalena; Mujica Lainez, Manuel; Mujica, Manuel; Mulock, Dinah; Munoz, Reynon; Murakami, Haruki; Murakami, Ryu; Murena, Hector Alvarez; Murphy, Pat; Musashi, Miyamoto; Musset, Alfred de; Nabokov, Vladimir; Najlis, Michele; Nathanson, E.M; Nelson, Alan; Neron; Neruda, Pablo; Nervo, Amado; Nestares, Carmen; Neville, Katherine; Nietzsche, Friedrich; Niven, Larry; Nolte, Phillip; Nomanor; 
Nooteboom, Cees; Norman, John; Nostradamus; Novelli, Aldo Luis; Nunez Cabeza de Vaca, Alvar; Nyberg, Bjorn; O Brian, Patrick; O Dell, Scott; Oesterheld, Hector; O Henry; Olaizola, Jose Luis; Oliver, Chad; Omar Khayyman; Ondaatje, Michael; ONeill, Gerard K; Onetti, Jorge; Orczy, Baronesa de; Ortega y Gasset, Jose; Orwell, George; Ossendowski, Ferdinand; Ovidio; Ozalu, Dazai; Palacios, Jesus; Palladino, Osvaldo; Pallares, Jose Manuel; Palma, Felix J; Palma, Ricardo; Papalia Dardo Adolfo; Papini, Giovanni; Pardo Bazan, Emilia; Pardo de Carugati, Dirma; Pariona Quispe, Angelo; Parker, Dorothy; Parra, Eduardo Antonio; Parra, Nicanor; Pavese, Cesare; Payne Brennan Joseph; Payro, Roberto J; Paz, Marcela; Paz, Octavio; Pazo, Jose; Paz Soldan, Edmundo; Paz Soldan y Unanue, Pedro; Peake, Mervyn; Pedraza, Juan de; Peiro, Joan; Pelaprat, Jean; Pelly, James; Pendelton, Michelene; Perea, Hector; Pereda, Jose Maria; Perez Agusti, Adolfo; Perez Castejon, Cristobal; Perez Galdos, Benito; Perez Reverte, Arturo; Perez Zaragoza Godinez, Agustin; Perrault, Charles; Perry, Steve; Perucho, Joan; Pessoa, Fernando; Petras, James; Petronio; Pierce, Ambrose; Pierce, John R; Pilniak, Boris; Pinkola Estes, Clarissa; Piper, H. Beam; Pirandello, Luigi; Pirenne, Henry; Pisabarro, V; Pitagoras; Pizarnik, Alejandra; Pizzi, Rogelio; Plans, Juan Jose; Plansky, Roman; Platon; Plotino; Poe, Edgar Allan; Pohl, Frederik; Pohl, Frederik + Cyri Kornbluth; Polia, Mario; Polidori, John W; Polo, Marco; Ponce Eduardo; Poniatowska, Elena; Portantiero, Juan C; Potocki, Jan; Pournelle, Jerry; Powers, Tim; Powers, William T; Prado, Luis G; Prado, Pedro; Pratchet, Terry; Pratchett, Terry; Price, E Hoffman; Priest, Christopher; Printz, Thomas; Proust, Marcel; Pua, Carlos de la; Puig, Manuel; Pullman, Phillip; Pushkin, Alexander; Puzo, Mario; Queen Ellery; Quevedo, Francisco de; Quick, Amanda; Quinn, Chelsea; Quintana, Carles; Quintana, Manuel Jose; Quintanilla Felix; Quintanilla Penagos, Jorge Arturo; Quiriny; Quiroga, Horacio; Radcliffe, Ann; Radiguet, Max; Rajo, Sebastian; Ramirez Heredia, Rafael; Ramirez Sergio; Ramos, Juan Antonio; Rampa, Lobsang; Recasens, Andres; Redal, Javier; Reduendeles, Cesar; Reed, Kit; Reeds, Joseph M; Renault, Mary; Rendueles, Cesar; Rendueles, Jose Luis; Resnick, Mike; Restrepo, Laura; Reveco, Johnny; Revueltas, Jose; Rey de Sola, Javier; Reyes, Alfonso; Reynolds, Mack; Rhodes, James Montague; Rice, Anne; Rilke, Rainer Maria; Rimbaud, Jean Arthur; Rivas, Duque de; Roa Bastos, Augusto; Roberts, Keith; Roberts, Nora; Robertson, Morgan; Robinson, Spider; Rocklynne, Ross; Rojas, Fernando; Rojas, Manuel; Rojas Zorrilla, Francisco; Romano, Vicente; Romero, Pedro J; Romero y Larranaga, Gregorio; Ropero, Javier; Ros de Olano, Antonio; Rosemberg, Tina; Rouchefoucault, Francois de la; Rousseau, Jean; Rowling, J.K; Rucker, Rudy; Ruiz de Alarcon, Hernando; Ruiz de Alarcon, Juan; Ruiz Fernandez, Francisco; Ruiz Zafon, Carlos; Rulfo, Juan; Russell, Eric Frank; Russ, Joanna; Rutherford, Derek; Ryan, Lem; Ryunosuke, Akutagawa; Sabato, Ernesto; Saberhagen, Fred; Sabines, Jaime; Sade; Saez de Melgar, Faustina; Safo; Sagan, Carl; Saguier, Raquel; Saint Exupery, Antoine de; Saiz Cidoncha, Carlos; Saki; Salas, Antonio; Salgari, Emilio; Salinger Jerome, David; Salvador, Tomas; Samaniego; Sampedro, Jose Luis; Sanchez, Florencio; Sanchez, Miguel; Sanchez Ramos, Richard; Sand, George; Sanguinetti, Eduardo; San Ignacio de Loyola; San Juan de la Cruz; San Nilo; Santa Teresa de Avila; Santa Teresa de Jesus; Santiago, Juan Manuel; Santiago y Gadea, Augusto; Santos, Domingo; Santos, Luis Martin; Sapper, Karl; Saramago, Jose; Sarlo, Beatriz; Sarmiento Domingo, Faustino; Sartorius, Carl; Sartre, Jean Paul; Sartre, Jean Paul y Camus, Albert; Savater, Fernando; Savers, Dorothy L; Sawa, Alejandro; Schedrin, Saltikov; Scherzer, Carl; Schiele, Egon; Schiller, Friedrich von; Schmitz, James H; Schmitz, James H; Schopenhauer, Arthur; Schowb, Marcel; Schuster, Adolf N; Schweitzer, Albert; Scortia, Thomas; Scott Card, Orson; Scott, Robin; Scott, Walter; Scribe E; Seabrook, W. B; Seler, Eduard; Sender, Ramon J; Sepulveda, Luis; Sepulveda, Luis y Delgado, Aparin Mario; Serling, Rod; Serrano, Marcela; Sewell, Anna; Shakespeare; Shan, Darren; Sharkey, Jack; Shaw, Bob; Sheckley, Robert; Sheffield, Charles; Shelley, Mary; Shelley, Percy Bysshe; Shepard, Lucius; Sheridan Le Fanu, Joseph; Shiel, M. P; Shintaro, Ishihara; Sholojov, Mijail; Shrout, Richard; Shua, Ana Maria; Sicardi, Francisco A; Sievers, Wihelm; Silverberg, Robert; Silvero, Anibal; Silvestre, Armand; Simak, Clifford D; Simenon, Georges; Simmons, Dan; Simon Abril, Pedro; Sinoue, Gilbert; Sivers, Jergor von; Skarmeta, Antonio; Skinner, B.F; Sladek, John T; 
Smith, Adam; Smith, Clark Ashton; Smith, Cordwainer; Smith, Edward E; Sobel, Dava; Soboul, Albert; Socrates; Sofocles; Sohl, Jerry; Sol, Andrea; Solanes Venzala, David; Solis, Gilberto; Sontag Susan; Soriano, Osvaldo; Spencer, Johnson; Spinoza; Spinrad, Norman; Sprague de Camp L; Springer, Nancy; Spyri, Johanna; Srila, Atulananda; Sri Ramana Maharshi; Stagg, John; Stapledon, Olaf; St. Clair, Margaret; Steffenen, Hans; Steiger, Brad; Steiger, Brad y Sherry; Steinbeck, John; Stendhal; Stephenson, Neal; Sterling, Bruce; Sternberg, Jacques; Stesicoro; Stevenson, Robert Louis; Stewart, George R; Stewart, Mary; Stine R. L; Stirner, Max; Stocker, Bram; Stocks, John Leofric; Storm, Theodor; Storni, Alfonsina; Stowe, Harriet Beecher; Straub, Peter; Strugatsky, Arkadi y Boris; Stubel, Uhle; Sturgeon, Theodore; Suarez, Jose Antonio; Suetonio; Suner Iglesias, Francisco Jose; Susel, David; Suskind, Patrick; Sutcliffe, Katherine; Swann, Thomas B; Swanwick, Michael; Swift, Jonathan; Takuan; Tales de Mileto; Tasso, Torcuato; Temple, William F; Tenn, William; Tensin Giatso; Tereschuck, Carlos; Thackeray, W. M; Thomas, Theodore L; Thorkent, A; Thorne, Kip S; Tieck, Johann L; Tiptree Jr., James; Tirso de Molina; Tolkien, J.R.R; Tolman, Edward; Tolstoi, Leon; Torrente Ballester, Gonzalo; Torres, Gracia; Torres Quesada, Angel; Traven, B; Trechera, Rafael Marin; Trigo, Felipe; Tritten, Charles; Trivino, Consuelo; Trotsky, Leon; Tubb, E. C; Tucci, Giusseppe; Tucker, Wilson; Turguenev, Ivan; Turner, George; Turner, John Kenneth; Turtledove, Harry; Turtledove, Turtle; Twain, Mark; Tyers, Kathy; Tynan, Kenneth; Umbral, Francisco; Unamuno, Miguel de; Urdapilleta, Alejandro; Valades, Edmundo; Valdes, Alfonso de; Valdes, Zoe; Valente, Jose angel; Valera Cid, Eduardo; Valera, Juan; Valery, Paul; Valle Inclan, Ramon Maria; Vallejo, Cesar; Vallejo, Fernando; Vanasco, Alberto; Vance, Jack; Van Gogh, Vincent; Van Hageland, A; Van Lustbader, Eric; Van Vogt, Alfred. E; Vaquerizo, Eduardo; Varela Cid, Eduardo; Vargas Llosa, Mario; Varios Autores; Varley, John; Varshavsky, Ilya; Vasconcelos, Jose Mauro; Vazquez, Carlos D. J; Vazquez Figueroa, Alberto; Vazquez Montalban, Manuel; Vega Contreras, Luis; Vega, Garcilaso de la; Vega, Lope de; Vega y Carpio, Felix Lope; Velarde, Jose Luis; Verga, Giovanni; Verne, Julio; Veron, Eliseo; Vespucio, Americo; Viadel, Luis; Vian, Boris; Vicedo, Jose Maria; Vidal, Gore; Vilanova, Arnau de; Vilches, Julio; Villegas Carballo, Anna Silvia; Villiers de l'Isle, Adam Auguste; Villoro, Juan; Vinge, Vernor; Virgilio; Virilio, Paul; Vizconde de Taunay; Volante, Norberto; Volpi, Jorge; Voltaire; Vonnegut, Kurt Jr; Wagner, Karl Edward; Waldrop, Howard; Wallace, Inez; Walpole, Horace; Walsh, Rodolfo; Washington, Irving; Watson, Ian; Waugh, Evelyn; Wegmann, Osvaldo; Weinbaum, Stanley G; Weinberg, Robert; Weis, Margaret; Weis, Margarete y Tracy Hickman; Wells, Herbert George; White, EB; White, George H; Wilde, Oscar; Wilhelm, Kate; Williamson, Jack; Williamson, lan; Williams, Tennessee; Williams, Walter J; Willis, Connie; Wilson, Colin; Wilson, F. P; Wilson, Richard; Wodehouse, P.G; Wolfe, Gene; Wollheim, Donald A; Woolf, Virginia; Worms, Hugo de; Wyndham, John; Wynne, Madelene Yale; Wynorski, Jim; Yoko, Ogawa; Yolen, Jane; Young, Robert F; Yourcenar, Marguerite; Yukio, Mishima; Zahn, Timothy; Zamyatin, Yevgeni; Zapata; Zayas y Sotomayor, Maria de; Zebrowski, George; Zelazny, Roger; Zimmer Bradley, Marion; Zola, Emile; Zola, Emilio; Zorrilla de San Martin, Juan; Zorrilla, Jose; Zweig, Stefan

(C) 2021 By AIRCC Publishing Corporation. This article is published under the Creative Commons Attribution (CC BY) license. 